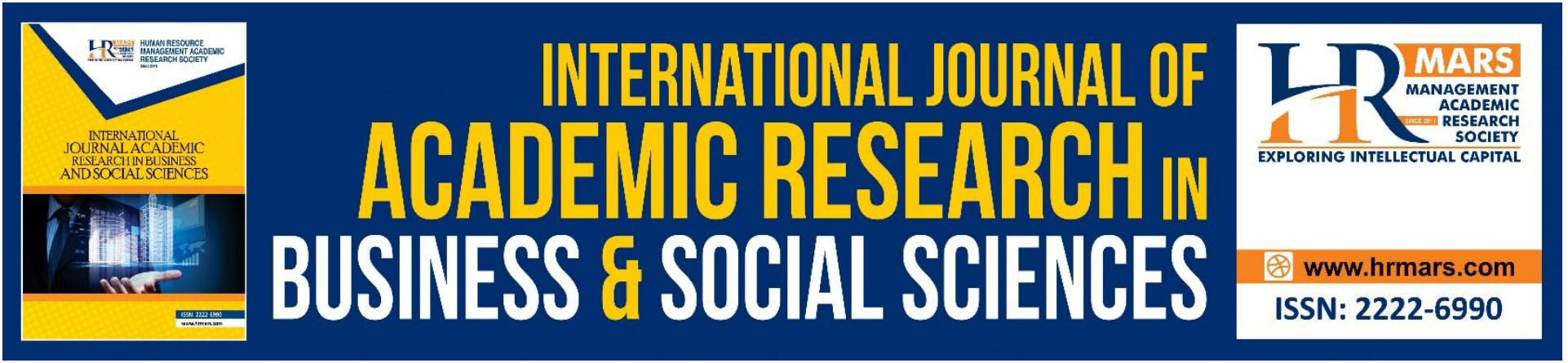

\title{
Chinese Cultures and the Practices of Islamic Teachings
}

\author{
Mohd Fitri Muhamed, Anuar Puteh, Razaleigh Muhamat @ Kawangit
}

To Link this Article: http://dx.doi.org/10.6007/IJARBSS/v11-i10/11495 DOI:10.6007/IJARBSS/v11-i10/11495

Received: 18 August 2021, Revised: 21 September 2021, Accepted: 10 October 2021

Published Online: 24 October 2021

In-Text Citation: (Muhamed et al., 2021)

To Cite this Article: Muhamed, M. F., Puteh, A., \& Kawangit, R. M. @. (2021). Chinese Cultures and the Practices of Islamic Teachings. International Journal of Academic Research in Business and Social Sciences, 11(10), $1191-1199$.

Copyright: @ 2021 The Author(s)

Published by Human Resource Management Academic Research Society (www.hrmars.com) This article is published under the Creative Commons Attribution (CC BY 4.0) license. Anyone may reproduce, distribute, translate and create derivative works of this article (for both commercial and non-commercial purposes), subject to full attribution to the original publication and authors. The full terms of this license may be seen at: http://creativecommons.org/licences/by/4.0/legalcode

Vol. 11, No. 10, 2021, Pg. 1191 - 1199

Full Terms \& Conditions of access and use can be found at http://hrmars.com/index.php/pages/detail/publication-ethics 


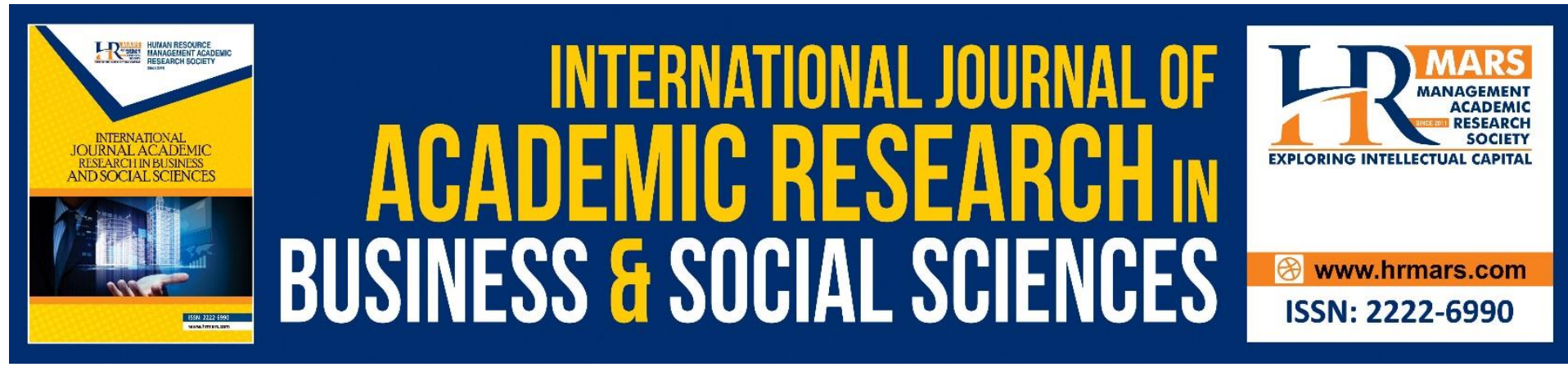

\title{
Chinese Cultures and the Practices of Islamic Teachings
}

\section{Mohd Fitri Muhamed, Anuar Puteh, Razaleigh Muhamat @ Kawangit}

Research Centre for Dakwah And Leadership Faculty of Islamic Studies National University of Malaysia, Malaysia

\begin{abstract}
This article explores the Chinese cultures which are similar to the practices of Islam that can be continued by new converts. Although Islam is recognized as a universal religion, there are still those who still think that with the introduction of Islam will cause a change to their original identities and eliminate racial identity that has been held for generations. In Malaysia, for example, there is an understanding amongst the people of China that "Islam means being a Malay" which practices the culture of their ancestors. Based on this study, there are cultural practices of the Non-Muslims that are actually similar to the practices in Islam that are distinguished by beliefs and ways of implementation. Culture is seen as a factor that can be misunderstood with little change in terms of ways and beliefs. The research method is qualitative with the document analysis method in which the documents are reviewed by the researcher to evaluate the evaluation theme, proving that Islam does not completely reject the culture of any race as long as it does not contradict to the basics of Islam itself. Islam does not eliminate the identity of a race.
\end{abstract}

Keywords: New Converts, Culture, Islamic Practices, Chinese Community.

\section{Introduction}

Life can be seen from the aspects of religion and culture, which are related to each other (Meerangani et al., 2018). However, there are many things that are misunderstood by some people who do not have the understanding of how to place the position of religion and culture in a society. In the community, religion and culture clearly do not stand alone, the two have a very close relationship in their daily lives (Nurshahumizam, 2018). Religion guides and a guidance to human who were created by God. While the culture in a society is created from the results of practices inherited from their ancestors (Bauto, 2014). Religion and culture influence each other. Religion affects cultures, community groups, and ethnic groups. Culture of a society will change affecting the policies of religious practices so as to give rise to different interpretations. One of the big agendas in the life of the community, nation and is to maintain association and unity and develop the well -being of national life with the whole community despite being different in religion and cultures (Fadli, 2010).

Religion is defined as the relationship between human beings with an extraordinary power that is considered to provide protection and guidance in daily lives. This sacred 
relationship encourage man to be more obedient and submissive to his creator Baharuddin, 2007). From an anthropological perspective, Geertz sees religion as a cultural system symbolized by symbols that highlight the religious image of a religious community (Yasin \& Adam, 2017). The best appreciation of religion in life is to practice religious teachings in all dimensions such as in the way of thinking, acting, communicating in accordance with religious knowledge and understanding (Ghani et al., 2005).

Culture can be observed from a society's behavioural activities. Human behaviour is driven by various aspects such as values, norms, customs, rules, belief, law and so on. The adaptation of human behaviours fundamental to the growth of culture (Rani, n.d.). According to Edward B. Taylor culture is a complex containing knowledge, beliefs, art, morality, law, customs and other abilities and habits acquired by humans as members of a society (Naibei, 2014). According to Alfred L. Kroeber, Culture consists of explicit (obvious) and implicit (implicit) patterns of behaviours, which are acquired and conveyed through cultural symbols, the core of a culture consists of ideas that narrated by tradition (which arises and is selected in a historical process). The practices will continue to be practiced through the generations.

\section{Problems Statement}

When there is a change of religion, converts will face various conflicts in order to adapt the practices of Islam. Embracing Islam changed the norm of one's life (Awang, 2015). The change raised issues of concern among new converts due to misunderstandings, especially in terms of relationships with one's own family that are non-Muslims.

Based on previous studies conducted by scholars, among them is (Yu \& Joy, 2005) revealed in his study that major issues that arise in the relationship between the converts and non-Muslim families are Cultural issues and religious value (Lam \& Joy, 2005). Next, according to Shaharuddin et al (2013) family members consider converting to Islam is an act of betrayal, because they think that Islam is only for the Malays. Embracing Islam is considered a betrayal and insult to the ancestors and their practices and converting to Islam is considered of breaking family ties.

Although a lot of researchers have been done on new coverts, there are still areas to be studied in towards understanding the Islamic practices. Abdullah (2006) stated that new converts face several problems such as culture, confusion, religious knowledge and difficulty to understand Islam and misunderstanding of Islam

In this regard, the research tried to explain that Islam does not totally reject the culture of a race as long as it does not contradict the Islamic practices and to eliminate the worries of the Chinese community regarding relationship with their family after embracing Islam.

\section{Discussion and Analysis}

Malaysia is known around the world as a rapidly developing country. Malaysia is also known as a unique Islamic country because of its multi -racial population and different beliefs and religions. The great majority of its citizens are Muslim Malays because Malaysia is their homeland.

Malaysia is currently inhabited by people of various races and ethnic. With the existence of various races and ethnicities, there is also a diversity of cultures, languages, religions and customs.

Malaysian society contains more than one race and has its own characteristics in terms of culture, values and norms of life. Although Malaysia has a diversity of cultures, they can 
interact with each other with respect between the races and mutual care and manners when related to the different religion, customs and culture of other races. This is stated in the words of Allah surah Al-Hujurat verse 13:

Which means: O mankind, we created you from a male and a female and made you into nations and tribes that you may know one another. The noblest of you in the sight of Allah is the most pious. Allah is knows, Aware.

\section{Child Birth}

\section{a. Physical attributes determine future}

Chinese believe that protruding navel are associated with poor living. They will also associate wide and thick ears as a sign of a rich life. Chinese people believe that if there is more than one navel head on the head, the baby will be naughty. The hollowed navel is a which they believed to life.

In Islam, a baby's birth baby born has been determined by qada 'and qadar (Rahman, 2006). The words of Rasulullah S.A.W narrated by Muslim:

Meaning: "Each life is collected in his mother's womb in a state of semen for forty days, then turned into a piece of blood for forty days, then into a lump of flesh for forty days. Then an angel was sent to him to prescribe four things: His sustenance, his death, his deeds and his end whether suffering or happiness. There are some of you who do the deeds of the people of heaven, but a provision has been set for him, then he did the deeds of the people of hell, then he entered hell. Indeed, there are among you who do the deeds of the people of, but a provision has been set for him, then he does the deeds of the people of heaven, then he enters paradise."

\section{b. Shaving Baby Hair}

Chinese practice the shaving of baby's hair because baby's hair that came is temporary and need to be shaved for new hair. This custom as a recognition for the birth into the society (Yusoff, 2018).

In Islam, the culture of shaving the hair on the seventh day is encouraged by Syarak. This is based on a hadith from Sayidina Ali R.A, which means: "Rasulullah S.A.W sacrificed a goat for al-Hasan and then said:" O Fatimah, shave his hair and in silver as the weight of the hair. " Ali said: "The weight is equal to one dirham or half a dirham." History of al-Tirmizi (1519)

\section{c. Baby Name Determination}

In naming a child there are customs and rules that are needed to be followed. Chinese names consist of 3 words that begin with a family name. The second phrase represents the name of a generation among siblings and relatives. The third name is the baby's own name ( Muniandy, n.d.).

There are five important aspects that needed to be considered in naming a new born baby, that is, the name given should contain a good meaning such as a symbol of wealth, luxury and well -being. Next, the sound of the name must be pleasant to hear and the name must be made based on mathematical calculations i.e., the resulting numbers should show good fortune. The name given must comply to Yin and Yang elements and must include five elements namely gold, water, fire, earth and wood and complimentary to each other (Muniandy, n.d.). 
In Islam, the determination of the child's name should also be made with good names and names that are not enslaved other than to Allah Taala and does not have elements of shirk. The words of Rasulullah SAW narrated by Abu Dawud which means: "Indeed, you will all be called on the Day of Judgment by your names and the names of your fathers, so beautify your names"

Researchers are of the view that it is not wrong for the Chinese to use the original names of their ancestors as long as they have good meanings. Dr Yusuf al-Qaradhawi argues that: "The scholars of Fiqh:" The scholars of jurisprudence do not forbid as naming children with non-Arabic names as long as the meaning is good. Many Muslims retain non -Arab names for men and women after converting to Islam even though they are in Arab life and culture.

\section{Wedding Culture}

a. Candidate Selection

Before modern times, women were not allowed to choose a partner to marry. Instead, the bride's family chooses her future husband. Marriage is chosen based on the need for reproduction and good name of the family, as well as the needs of the father and her husband. (Chek, 2010).

Next, during courtship when a son's parents decide for a daughter -in -law, they will look for a spy whose mediator task is to reduce conflicts of interest as well as embarrassment when discussing possible marriages between the two families who are usually not ( Haziq, n.d.). The mediator will do a birth date comparison, if the family of the daughter -in -law does not object to the proposal, the mediator will compare the couple's birthday. If the pair is suitable according to Chinese astrology, they will proceed to the next step.

Whereas according to Islam, the choice of a wife for a man who intends to start a family is something that needs to be discussed carefully so that the couple can live happily (Ismail \& Muhammad 2017). Choosing a suitable and compatible wife is a complicated afford which requires. In Islam the concept of marriage is permanent.

Rasulullah S.A.W gives guidance to men on tips to find a suitable partner. The words of Rasulullah S.A.W as recorded by Bukhari:

Meaning: "Married to a woman for four things: because of her wealth, her lineage, her beauty, and her religion. So choose the one who is religious, you will surely benefit."

In the hadith, Rasulullah S.A.W explained that there are four bases on a prospective wife, wealth, good lineage, beauty and women with religious beliefs. In the matter of choosing a mate, Rasulullah S.A.W suggested choosing a religious woman will provide happiness for the family. The dignity of a woman can be judged through the aspects of her religion as well as the religious values practiced in her life (Nurdin, 2017).

\section{b. Engagement}

The determination of the dowry which is an engagement gift where the son's family will arrange for a mediator to deliver will, include the engagement letter to the bride's family ( Angita, 2014). Wedding gift varies, depending on local customs as well as family's wealth. Food and delicacies are common gifts. Wedding will be determined based on Chinese calendar calculation.

Engagement in Islam to know is a period getting to know the future spouse before marriage (Chek, 2010). In a hadith, Rasulullah SAW said to a friend who wants to get engaged which means: "Look at the woman first because it will further maintain the love between the two of you." History of al-Tirmizi (1087). Therefore, in Islam, emphasis is also placed on the 
aspect of engagement before marriage, but it is not obligatory for the man to give any engagement gift for the future wife and future in-laws, in fact, it would not be an offense if no celebration was held Sitiris \& Mohamad, 2017).

\section{c. Wedding Ceremony}

The wedding procession from the bride's house moves to the groom's house using a carriage and is accompanied by a traditional band, a team of bridesmaids (if any), as well as the bride's dowry ( Johari et al., 2020).

There are certain ceremonies performed to welcome the bride and members of the procession into the groom's house ( Haziq, n.d.). In Chinese society, the wedding banquet is known as xǐ-jǐu which literally means "wine of joy", and is sometimes far more important than the wedding ceremony. There are also ceremonies such as pouring wine or tea for parents, couples, and guests.

In Islam, the wedding feast (Walimah al-'Urus) is a Shariah requirement. Some scholars noted it is obligatory, while some others observed the requirement as sunat muakkad ( Husin, 2017).

According to Jumhur, holding the walimah is sunat because the walimah is an occasion of joy (JAKIM, 2013). Walimah best carried out in moderation without burdening the family in hadith of the Prophet S.A.W narrated by Bukhari which means, "Make a feast even with just a lamb."

\section{Managing Death}

\section{a. Funeral Services}

When death occurs in a Chinese society, the deceased will be cleaned and bathed showing respect to the deceased. After bathing, the deceased perfumed. In their belief, this will make the deceased fragrant, especially for the hereafter. Then the deceased is dressed in beautiful clothes and usually the clothes worn during the wedding day. The deceased are also dressed with other accessories. Then the deceased will be placed in a coffin, for the rich, the coffin is carved with metal. Added, showing a person's position during his life (Ling, 2018).

Family members, relatives and friends are required to mourn for the passing of the deceased. The cries should be done loudly as the deceased is placed in the living room until it is taken to the buried cemetery (Ling, 2018).

In Islam the deceased will be bathed. After bathing and ablution, the corpse will be dried using a towel before the shrouding process begins ( Yusof @ Salleh, Rahim, Hassan, 2017). The deceased will be wrapped in a cloth called "Kafan" covering the whole body. The fabric used for this purpose should not bright. It is also encouraged to spray / smear fragrances that do not contain alcohol and prohibited substances (Omar, n.d.).

Accompanying and visiting the grave is to remember death and the Day of Judgment. The words of the Prophet S.A.W. "I used to forbid you to visit the cemetery. But now visit the cemetery (because there are benefits) (Muslim Narration).

Crying excessively and roaring is not allowed (Abdullah, 2020). However, crying and grieving is not forbidden because it is human natural attribute. Rasulullah s.a.w. himself once mourned for the passing of his son Ibrahim.

\section{b. Funeral Affairs}

In ancient times, Chinese people carried the deceased using a carriage made of carved wood, usually the carving symbolized the status of the deceased. Various types of religious 
songs or traditional songs as a symbol of grief and condolence. Favourite songs of the deceased are played along the procession to the cemetery ( Fauziah, 2019). Music are played from the house until the deceased is buried. The music will not stop this to entertained the dead until they are in the afterlife. Usually on that day, family members of the deceased will wear black. Other colours are not recommended, red is forbidden as it disrespects the deceased and his family. When the deceased is taken using a special truck, metal coated paper toasted along the way. It is believed that, the spirit can walk home guided by these paper.

In Islam it is fardhu kifayah to perform the funeral prayers for their deceased. Bathing, shrouding, burial are a sunat. Accompanying the deceased to the grave and to sit for a while to pray for the deceased. Praying for the deceased to answer all the questions from the Angel Munkar and Nakir and get forgiveness and mercy from Allah S.W.T.

It is forbidden for the family of the deceased to cry (crying out loud / howling, tearing clothes, slapping cheeks, hitting the body, pulling hair). This prohibition is based on the words of the Prophet Muhammad SAW:

Meaning: "Two things that are from the actions of the infidels: disrespecting one's ancestor (of a person) and mourning over the corpse." (Muslim Narration)

However, it is permissible to cry/shed tears without making a sound as a sign of sadness over the death of a loved one (Bakri, 2015).

\section{Conclusion}

Islam is a universal religion and is based on faith. The advent of Islam is to bring blessings to all the creatures of Allah in the world. The words of Allah Almighty in Surah Al-Anbia, verse 107 which means, "And We did not send you (O Muhammad) but the mercy of all the worlds".

Islam does not completely reject the culture of new converts but is always openminded and open in celebrating as long as it does contradict to what has been outlined by Islamic requirement.

\section{Corresponding Author}

Razaleigh Muhamat @ Kawangit

Research Centre for Dakwah and Leadership Faculty Of Islamic Studies National University Of Malaysia, Malaysia.

Email: raza@ukm.edu.my

\section{References}

Abdullah, A. A. (2020). Mengingati Mati Dan Peringatan Untuk Mati : Renungan Untuk Yang. October 2014.

Abdullah, S. (2006). Pemikiran dan Sistem Kepercayaan Masyarakat Peranakan Cina di Melaka Tengah. Akademi Pengajian Islam.

Angita, Y. (2014). Gambaran Kehidupan Perempuan Cina Tradisional.

Awang, A. (2015). Bentuk-bentuk Hubungan Muslim- Non Muslim Selepas Pemelukan Agama: Kajian Kes Dalam Kalangan Mualaf Cina Terengganu. Jurnal Kemanusiaan, 23.

Baharuddin, S. A. (2007). Modul Hubungan Etnik. Pusat Penerbitan Universiti Teknologi MARA.

Bakri, Z. M. (2015). No Adab Islam Bagi Menghadapi Kematian. Pejabat Mufti Wilayah Persekutuan. https://muftiwp.gov.my/artikel/bayan-linnas/2588-bayan-linnas-siri-ke13-adab-islam-bagi-menghadapi-kematian

Bauto, L. M. (2014). Perspektif Agama dan Kebudayaan dalam Kehidupan Masyarakat 
Indonesia. Jurnal Pendidikan Ilmu Sosial, 23(2).

Chek, R. (2010). Konsep perkahwinan dalam Agama Islam. 26-82. http://studentsrepo.um.edu.my/5182/

Fadli, K. (2010). Peranan Pendakwah Dalam Pembangunan Ekonomi Masyarakat Medan Indonesia. 9(1), 76-99.

Fauziah, S. S. (2019). Upacara Kematian dan Budaya Berkabung di Kalangan Masyarakat Cina Benteng Tangerang Kota.

Ghani, Z. A., Mansor, A., \& Salimah, N. (2005). Penghayatan Agama Sebagai Asas Pembangunan Pelajar: Analisis Terhadap Beberapa Pandangan Al-Imam Al-Ghazali. National Student Development Conference (NASDEC)., 1-19.

Haziq, M. (n.d.). Persamaan adat perkahwinan kaum melayu, cina dan india.

Husin, S. N. M. S. (2017). Masyarakat Melayu Muslim Menurut Akademi Pengajian Islam. 98. https://core.ac.uk/download/pdf/268878635.pdf

Ismail, A. M., \& Muhamad, A. R. (2017). Analisis Awal Pemilihan Jodoh Kaum Lelaki di Kota Bharu, Kelantan. AL-Hikmah, 9(1), 3-24.

JAKIM. (2013). Pengurusan nikah.

Johari, N. I. M., Said, T. S., \& Ramli, H. (2020). kesinambungan warisan kesenian langkasuka di tanah melayu. International Journal of the Malay World and Civilisation, 8(2), 51-62.

Ling, T. Y. (2018). Upacara Ritual Gong Tek Masyarakat Teo Chew Cina Di Malaysia: Muzik, Teks dan Gerakan.

Meerangani, K. A., Ibrahim, A. F., \& Johar, M. H. M. (2018). Prinsip Asas Interaksi Inter-Agama Di Malaysia Menurut Perspektif Islam. Prosiding Kolokium Penyelidikan Kebangsaan 2018 Kolej Universiti Islam Melaka, January, 872-885. https://www.academia.edu/35818858/PRINSIP_ASAS_INTERAKSI_INTERAGAMA_DI_MALAYSIA_MENURUT_PERSPEKTIF_ISLAM

Muniandy, D. (n.d.). Info Adat Masyarakat Melayu, India Dan China.

Naibei, P. (2014). Dispute, comflict and causes of enviromental conflict in Kenya. European Environmental Policy, October, 78-92. https://doi.org/10.1016/b978-0-408-106894.50009-7

Nurdin, Z. (2017). Etika mencari pendamping hidup menurut islam. Syi'ar, 17 (1).

Nurshahumizam. (2018). Warisan Budaya Cina. 1-4.

Omar, J. J. G. (n.d.). Adat Kematian Kaum Melayu.

Rahman, S. M. S. H. (2006). Permasalahan sekitar qada' dan qadar. Permasalahan Sekitar Qada' Dan Qadar, 7, 63-92.

Rani, A. M. (n.d.). Konsep_Masyarakat_Dan_Budaya_Menurut_Isl.

Shaharuddin,S. A., Shaharuddin, H. N., Abdullah, M. Y. M., Misra, M. K. A., \& Fauzan, A. S. (2013). Cabaran Dan Permasalahan Mualaf Dan Penyelesaiannya Oleh Hidayah Centre Foundation (Hcf). Journal of Chemical Information and Modeling, 53(9), 1689-1699. https://doi.org/10.1017/СBO9781107415324.004

Sitiris, M., \& Mohamad, N. A. (2017). Gantirugi Akibat Pembatalan Pertunangan: Menurut Fiqh serta Amalannya di Mahkamah Syariah. Proceedings of International Conference on Law and Islamic Jurisprudence, April 2018. http://irep.iium.edu.my/id/eprint/63335

Yasin, S. K., \& Adam, F. (2017). Sensitiviti Agama Dalam Hubungan Masyarakat Pelbagai Kaum Di Malaysia. Proceeding of International Conference of Empowering Islamic Civilization, 1948, 17-22.

Yu, L. Y., \& Joy. (2005). Religous Conversion and Reconstruction Of Indentities: The Case of Chinese Muslim Convert in Malaysia. National University Of Singapore. 
Yusof, M. Y., Afandi, R. A. R., Paiz, H., Abd Munir, M. N., \& Halim, M. Z. Z.A. (2017). Beberapa Aspek Kearifan Tempatan Terhadap Bahan Alami Yang Digunakan Dalam Pengurusan Jenazah Rantau Alam Melayu. Idealogy, 2(1), 14-25.

Yusoff, M. Y. M. (2018). Pemuliharaan Warisan Budaya Melalui Perundangan Conservation of Cultural Heritage Through Heritage Legislation and Enforcement in Malaysia. Jurnal Melayu, 17(2), 143-159. 